\title{
Methotrexate binds to recombinant thiopurine $S$-methyltransferase and inhibits enzyme activity after high-dose infusions in childhood leukaemia
}

Patricia Wennerstrand, Lars-Göran Mårtensson, Stefan Söderhäll, Malin Lindqvist Appell and Anna Zimdahl

\author{
Linköping University Post Print
}

\section{Tweet}

N.B.: When citing this work, cite the original article.

The original publication is available at www.springerlink.com:

Patricia Wennerstrand, Lars-Göran Mårtensson, Stefan Söderhäll, Malin Lindqvist Appell and Anna Zimdahl, Methotrexate binds to recombinant thiopurine $S$-methyltransferase and inhibits enzyme activity after high-dose infusions in childhood leukaemia, 2013, European Journal of Clinical Pharmacology, (69), 9, 1641-1649.

http://dx.doi.org/10.1007/s00228-013-1521-9

Copyright: Springer Verlag (Germany) http://www.springerlink.com/?MUD=MP

Postprint available at: Linköping University Electronic Press http://urn.kb.se/resolve?urn=urn:nbn:se:liu:diva-80190 
Methotrexate Binds to Recombinant Thiopurine S-methyltransferase and Inhibits Enzyme Activity after High-dose Infusions in Childhood

\section{Leukaemia}

Patricia Wennerstrand ${ }^{1}$, Lars-Göran Mårtensson ${ }^{1}$, Stefan Söderhäll ${ }^{2}$, Anna Zimdahl ${ }^{1,3}$ and Malin Lindqvist Appell ${ }^{3 *}$

(1) Department of Physics, Chemistry and Biology, Linköping University, Linköping, Sweden

(2) Childhood Cancer Research Unit, Department of Women and Child Health, Astrid Lindgren Children's Hospital, Karolinska University Hospital, Stockholm, Sweden

(3) Division of Drug Research, Department of Medical and Health Sciences, Linköping University, Linköping, Sweden

*Corresponding author: phone: +46 10 1031229; fax: +46 13 104195; e-mail:

malin.lindqvist.appell@liu.se 


\section{ABSTRACT}

\section{PURPOSE}

Important drugs in the treatment of childhood ALL are 6-mercaptopurine (6-MP) and methotrexate (MTX). Thiopurine methyltransferase (TPMT) is a polymorphic enzyme causing variability in 6-MP response and toxicity. During acute lymphoblastic leukaemia (ALL) treatment, we have investigated the fluctuation in TPMT enzyme activity over time, as well as the effect of high-dose MTX infusions on TPMT enzyme activity and 6-MP metabolites.

\section{METHODS}

Fifty-three children with ALL treated according to the NOPHO-ALL 2000 protocol were included. TPMT enzyme activity was measured at six different times starting from diagnosis until after the end of maintenance treatment. TPMT and 6-MP metabolites were measured before and 66 hours after start of high-dose MTX infusions. The interaction between MTX and TPMT was investigated in vitro using recombinant TPMT protein and a leukemic cell line.

\section{RESULTS}

Forty percent of TPMT wild-type individuals had deceptively low TPMT enzyme activity compared to genotype at the time of diagnosis. TPMT decreased significantly 66 hours after the start of high-dose MTX infusions (-9.2 per cent, $p=0.013$ ). MTX bound to recombinant TPMT protein and inhibited the TPMT enzyme to a remaining activity of 16 percent.

\section{CONCLUSIONS}

This study shows that TPMT genotyping should be preferred in children with ALL, since 40 per cent of TPMT wild-type children are at risk of initial under-dosing of 6-MP in cases where 
only TPMT enzyme activity is determined. MTX inhibits the TPMT enzyme activity after high-dose MTX infusions due to protein binding.

Keywords: Leukaemia, 6-mercaptopurine, methotrexate, pharmacogenetics, thiopurine smethyltransferase 


\section{Introduction}

In the Nordic countries, children diagnosed with acute lymphoblastic leukaemia (ALL) follow a common treatment protocol where stratification into risk groups based on prognostic factors determines the exact treatment schedule. Of the about 180 children annually diagnosed in the Nordic Countries, the Event-Free Survival is approximately 80 percent [1]. Treatment-related toxicity can be life-threatening and is the primary cause of less intensive, interrupted or even discontinued maintenance chemotherapy which can lead to an increased risk for relapse [2]. The antimetabolite 6-mercaptopurine (6-MP) is an important part of the ALL treatment and is partly metabolised by the enzyme thiopurine methyltransferase (TPMT).

TPMT activity varies within populations as a result of common genetic polymorphism [3]. Individuals carrying two non-functional TPMT alleles (1 out of 300 in Caucasian populations) are at an increased risk for severe side effects if treated with conventional thiopurine doses [4-5]. Approximately 9 percent of the Caucasian population are TPMT heterozygous or carrying one non-functional allele. Studies have shown that these individuals also benefit from dose reduction [4]. Since the implementation of the Nordic Society of Paediatric Haematology and Oncology NOPHO ALL-2000 protocol, it is mandatory to determine TPMT status before the start of 6-MP treatment.

In the NOPHO ALL-2000 protocol, MTX is given from the point of diagnosis (usually as intrathecal injections), used as an oral treatment during a maintenance treatment block, as well as in high-dose intravenous infusions starting in the consolidation therapy. For example for children treated according to the standard risk protocol, high-dose-MTX (HD-MTX) is given in a dose of $5 \mathrm{~g} / \mathrm{m}^{2}$ during a time of 24 hours and calcium folinate rescue $\left(15 \mathrm{mg} / \mathrm{m}^{2}\right)$ from 42 hours after the start of MTX infusion. In the maintenance therapy, MTX is given orally once weekly (20 mg/m²/kg bodyweight target dose) and 6-MP orally every evening 
from 17 weeks until 2 to 2.5 years after diagnosis. The administration of 6-MP and MTX affect S-adenosyl L-methionine (SAM) metabolism in the cell by inhibiting folatedependent regeneration of S-adenosyl homocysteine (SAH). Inhibition of DHFR by MTX (which thus inhibits formation of tetrahydrofolate) increases plasma concentration of SAH [6]. Both 6-MP and MTX inhibit de novo purine synthesis (DNPS) and the combination of 6-MP and MTX leads to a pronounced DNPS inhibition in vivo, compared to 6-MP or MTX alone [7].The interaction between the drugs is complex and cellular response to the drugs is prompt. In addition, genetic polymorphisms in gene encoding transporters (such as the reduced folate carrier) and enzymes involved in MTX uptake and metabolism affect the treatment outcomes and toxicity [8].

\begin{abstract}
Aim
6-mercaptopurine (6-MP) and methotrexate (MTX) are important drugs in the treatment of childhood ALL. Thiopurine methyltransferase (TPMT) is a polymorphic enzyme causing variability in 6-MP response and toxicity. We investigated the fluctuation in TPMT enzyme activity from time of diagnosis until after the end of maintenance treatment, as well as the effect of high-dose MTX infusions on TPMT enzyme activity and 6-MP metabolites. Recombinant protein was used to investigate binding of MTX to the TPMT protein and a leukaemic cell line to study effects on TPMT enzyme activity in vitro.
\end{abstract}




\section{Methods}

\section{Patients}

Following the NOPHO ALL-2000 protocol, fifty-three children with ALL were enrolled in this study. According to the protocol, patients were placed into risk groups depending on pre-therapeutic factors and treated accordingly. Classification criteria of risk groups are listed in Table 1 and use the following protocols: standard intensity, intermediate intensity, intensive, very intensive and extra intensive, respectively. Children following the standard or intermediate intensive protocol received $25 \mathrm{mg} / \mathrm{m}^{2}$ 6-MP per day from day 50 onwards, whereas $60 \mathrm{mg} / \mathrm{m}^{2}$ per day was given to children included in the intensive, very intensive and extra intensive protocols. During maintenance treatment (day from diagnosis dependent on protocol), standard daily target doses adjusted for TPMT status were as follows: TPMT wild-type: $75 \mathrm{mg} / \mathrm{m}^{2}$, TPMT heterozygous individuals $\left(50 \mathrm{mg} / \mathrm{m}^{2}\right)$ and TPMT homozygous defect individuals: $5-10 \mathrm{mg} / \mathrm{m}^{2}$. MTX was given orally in a target dose of $20 \mathrm{mg} / \mathrm{m}^{2}$, given once a week as a single dose. During high-dose MTX, the weekly oral MTX was suspended. Doses of 6-MP and MTX were always adjusted to the white blood cell count (target 1.5 to $\left.3.5 \times 10^{9} / 1\right)$, according to the NOPHO ALL-2000 protocol.

\section{Sampling}

Blood samples to determine TPMT enzyme activity were obtained at the point of diagnosis, days 15 and 29 (during induction treatment), 106 (beginning or end of consolidation dependent on protocol), at one occasion (approximately 400 days after diagnosis) during the maintenance treatment period, as well as at one occasion 3 to 24 months after cessation of maintenance treatment (Table 2). DNA was isolated to determine TPMT genotype from the sample obtained from the point of diagnosis. To determine the effect of HD-MTX infusions on TPMT, thioguanine nucleotides (TGN) and methylthioinosine monophosphate (meTIMP) levels, two separate blood samples were collected either at day 106 or at any time high-dose 
MTX infusions were given during maintenance therapy, one sample were taken prior to and one approximately 66 hours after the start of MTX infusion. Calcium folinate rescue were given 42 hours after the start of MTX infusion. Patients received red blood cell transfusions during the study period when needed. This study was approved by the Local Ethics Committee at Linköping University (Ref. no. 01-297). All children and/or their parents gave written consent for their blood samples to be used in research.

\section{TPMT genotyping}

DNA was isolated from whole blood using the QIAamp DNA mini kit (Qiagen, Germany, Hilden). Three common variants in the TPMT gene (238G $>$ C, 460G $>A$ and $719 A>G$ ) were searched for by pyrosequencing as previously described [9].

\section{TPMT enzyme activity assay in red blood cells}

TPMT enzyme activity was measured as previously described in Pettersson et al. (2002) by determination of the formation of 6-methylmercaptopurine (6-meMP) from 6mercaptopurine using radio-labelled S-adenosyl-L-methionine as the methyl donor. Product formation was measured using a scintillation counter. One unit of enzyme activity represents the formation of $1 \mathrm{nmol}$ of 6-meMP per millilitre of packed red blood cells (pRBC) per hour of incubation. Cut off points of $9.0 \mathrm{U} / \mathrm{ml} \mathrm{pRBC}$ and $2.5 \mathrm{U} / \mathrm{ml} \mathrm{pRBC}$ were used to distinguish high from intermediate enzyme activity and intermediate from low enzyme activity, respectively [10-11].

\section{Determination of TGN and meTIMP}

The concentrations of TGN and meTIMP were determined in washed red blood cells using high-performance liquid chromatography (HPLC) as described previously [11]. Results were expressed as pmol/8x10 8 RBC. ${ }^{\beta}$ Normalized metabolite levels were calculated by dividing the measured metabolite levels with daily 6-MP dose.. 


\section{In vitro incubations of the cell line MOLT4 and MTX}

MOLT4 cells, a human T-lymphoblastic cell line from American Tissue Culture Collection (ATCC, Rockville, USA), was cultured in RPMI1640 supplemented with 10 percent foetal calf serum (Gibco, Paisley UK) and sub-cultivated twice every week. Methotrexate (SigmaAldrich St Louis, USA) was dissolved in $50 \mathrm{mM} \mathrm{NaOH}$ and added to the cell culture (20 ml of $0.3 \times 10^{6}$ cells $/ \mathrm{ml}$ ) which gave the final concentration of $90 \mu \mathrm{M}$ and was incubated for 24 , 48 and 72 hours at $37^{\circ} \mathrm{C}$ in an atmosphere of 5 percent $\mathrm{CO}_{2}$. Cells incubated only with $\mathrm{NaOH}$ in the final concentrations as for the MTX treated cells (0.3 percent) were used as controls (control vehicle, CV). To check that the CV did not significantly influence the TPMT enzyme activity, untreated cells were also included in each experiment. All experiments were performed in triplicates and at each time point two culture flasks with the same treatment were harvested. At the time of harvesting $3.5 \times 10^{6}$ cells were transferred to a 50 ml-tube. The incubation was ended by removing the medium after centrifugation at $500 \mathrm{x} g$ for 10 minutes. The cell pellets were washed in $10 \mathrm{ml}$ PBS, centrifuged, re-suspended in $1 \mathrm{~mL}$ PBS and centrifuged again. The cell pellets were stored in $-80^{\circ} \mathrm{C}$ until protein extraction.

At the time for protein extraction, the pellets were placed on ice and sonicated $4 \mathrm{x} 5$ seconds in $500 \mu \mathrm{L}$ extraction buffer (50 mM Tris-HCl (pH 7.6), $2 \mathrm{mM}$ dithiothreitol (DTT), $0.5 \mathrm{mM}$ phenylmethylsulfonyl fluoride (PMSF), 20 percent glycerol and 0.5 percent Nonidet P40). Samples were vortexed and centrifuged at $30,000 \mathrm{x} g$ at $4^{\circ} \mathrm{C}$ for 15 minutes. The supernatants were collected and the protein concentration was determined using the DC Protein Assay (Bio-Rad Laboratories, Hercules, California, USA) using a standard curve of bovine serum albumin and measured at $750 \mathrm{~nm}$ by a Molecular Devices Versa Max Tunable Microplate Reader and the computer software Soft Max Pro v 5. 


\section{TPMT enzyme activity in MOLT4 cells}

The TPMT enzyme activity in MOLT4 cells was determined by measuring the rate of formation of 6-methyl-mercaptopurine from 6-MP using ${ }^{14} \mathrm{C}$-labeled S-adenosyl-Lmethionine as the methyl group donor [12]. An amount of $200 \mu \mathrm{g}$ of the total cellular protein was incubated in duplicates for 2 hours at $37^{\circ} \mathrm{C}$ in $400 \mu \mathrm{l}$ of $47 \mathrm{mmol} / \mathrm{l}$ potassium phosphate buffer (pH 7.5), supplemented with 3 mmol/l 6-MP, 0.4 mmol/l DTT, $0.2 \mathrm{mmol} / \mathrm{l}$ allopurinol, and a mixture of S-adenosyl-L-methionine (SAM) and ${ }^{14}$ C-labeled SAM (GE Healthcare, Uppsala, Sweden) giving a total SAM concentration of $10 \mu \mathrm{M}$. After 2 hours, all reactions were stopped by the addition of $2 \mathrm{ml}$ of acetonitrile. The organic phase was collected, evaporated and then reconstituted in $20 \mathrm{mmol} / \mathrm{l} \mathrm{KH}{ }_{2} \mathrm{PO}_{4}$ (pH 2.7) to total volume of $100 \mu \mathrm{L}$. A $50 \mu \mathrm{l}$ sample was analysed by high performance liquid chromatography using a Purospher STAR, RP18 (3 $\mu \mathrm{m}, 55$ x 4mm) column maintained at 30 C (MERCK, Darmstadt, Germany) with a Gemini C18 4 x 2mm precolumn from Phenomenex (Torrance, California, USA). The mobile phase consisted of $20 \mathrm{mmol} / \mathrm{KH}_{2} \mathrm{PO}_{4}$ (pH 2.7), with 15 percent methanol (v/v). The ultraviolet (UV) signal at $290 \mathrm{~nm}$ was used to determine the retention time for meMP and the signal of a scintillation detector was used to determine the enzyme activity. The TPMT enzyme activity of MTX treated cells were expressed as percentage of CV treated cells.

\section{In vitro studies using recombinant TPMT protein}

\section{Construction of TPMT variants}

Human wild-type TPMT, encoding residues 1-245, was cloned into vector pET28-Lic, generously provided by Structural Genomics Consortium (SGC; Toronto, Canada) and was transformed into the E. coli strain BL21-Codon plus (DE3)-RIL (Novagen, Gibbstown, New Jersey, USA) for large-scale expression. 


\section{Large-scale expression and purification}

E. coli BL21-Codon plus (DE3)-RIL, transformed with the plasmid pET28-Lic, was expressed in LB medium and cultivated at $37^{\circ} \mathrm{C}$ until OD600 reached 1.0, and then induced with isopropyl-beta-D-thiogalactopyranoside (IPTG) at a decreased temperature of $21^{\circ} \mathrm{C}$. After the harvesting and sonication of the cells, purification was performed on Ni-NTA Superflow (Qiagen, Hilden, Germany), the His-tag was removed with biotinylated thrombin (Novagen) and further purified on the Superdex 200 10/30 column (GE Healthcare Biosciences, Uppsala, Sweden). Protein was stored in a $20 \mathrm{mM}$ potassium phosphate buffer (pH 7.3), with $150 \mathrm{mM} \mathrm{NaCl,} 0.5 \mathrm{mM}$ Tris-2-carboxyethyl phosphine (TCEP) and 10 percent glycerol at $-80{ }^{\circ} \mathrm{C}$.

\section{Recombinant TPMT enzyme activity measurements}

Spectrophotometry was applied to measure the enzyme activity of recombinant TPMT with $84 \mu \mathrm{M}$ 6-mercaptopurine as substrate and measured at room temperature on a Hitachi-U2800 spectrophotometer [13]. The decrease in absorbance was monitored at $320 \mathrm{~nm}$ during 30 minutes using a TPMT protein concentration of $1 \mu \mathrm{M}, 1 \mathrm{mM}$ SAM and $200 \mu \mathrm{M}$ MTX in $20 \mathrm{mM}$ potassium phosphate (pH 7.3), $75 \mathrm{mM} \mathrm{NaCl,} 2$ percent glycerol, $0.5 \mathrm{mM}$ Tris-2carboxyethyl phosphine (TCEP). The enzyme activity was expressed as a percentage of the activity measured on TPMT protein incubated with CV.

\section{Fluorescence measurements}

To determine the binding constant of MTX to TPMT, MTX was titrated in an interval between 0 to $250 \mu \mathrm{M}$. Aliquots of $1 \mu \mathrm{l}$ MTX from a stock solution of $10 \mathrm{mM}$ MTX dissolved in $0.1 \mathrm{M} \mathrm{NaOH}$ were added to $1 \mu \mathrm{M}$ TPMT protein in $20 \mathrm{mM}$ potassium phosphate (pH 7.3), $75 \mathrm{mM} \mathrm{NaCl}, 2$ percent glycerol, and $0.5 \mathrm{mM}$ TCEP. Fluorescence 
measurements were performed at $21^{\circ} \mathrm{C}$ with the excitation wavelength of $295 \mathrm{~nm}$ specific for tryptophans and emission spectra recorded at 310-550 nm (Fluoromax-4 from Horiba). The maximum intensity of the Trp-fluorescence obtained at $340 \mathrm{~nm}$ was plotted against the increased concentration of MTX.

\section{Statistical analysis}

Statistical analysis was conducted using SPSS 19.0 (IBM SPSS Statistics 19) and Graph Pad Prism Software 5.01. For cell line experiments parametric statistics were used (mean and SEM) and differences between cell treatments were analysed using Student's t-test. For analysis of variables among patients, non-parametric statistics were used (median and interquartile range and to compare groups, Wilcoxon's test was used. A p-value $<0.05$ was considered significant. 


\section{Results}

A total of 53 children, with T or pre-B-ALL ages $7.5 \pm 4.6$ years (range 1-17 years) were included in this study (Table 1) and followed the NOPHO ALL-2000 treatment protocol. The majority (81 percent) were treated according to the standard and intermediate intensity protocol, whereas 11.3 percent were treated with the intensive protocol; 3.8 percent with the very intensive and 3.8 percent with the extra intensive protocol. Forty-nine children (92.5 percent) were genotyped as $T P M T^{*} 1 /{ }^{*} 1,7.6$ percent as heterozygous for one non-functional TPMT allele. None of the 53 children were TPMT deficient (TPMT $<2.5 \mathrm{U} / \mathrm{ml} \mathrm{pRBC}$ ) or carried two non-functional alleles. Samples of two of the wild type patients were only available at diagnosis and not for follow up.

\section{TPMT enzyme activity during treatment}

The median TPMT enzyme activity upon diagnosis was $9.5 \mathrm{U} / \mathrm{ml}$ pRBC (interquartile range 7.8 to 10.9 ) for TPMT wild-types ( $\mathrm{n}=47)$ and $4.7 \mathrm{U} / \mathrm{ml} \mathrm{pRBC}$ (interquartile range 4.6 to 5.2 ) for TPMT heterozygous individuals ( $\mathrm{n}=4)$. Of individuals with the TPMT genotype TPMT*1/*1, 40 percent had an initial enzyme activity at diagnosis below the cut off for normal activity (9 U/ml pRBC). All four heterozygous individuals (TPMT*1/*3A or TPMT*1/*3C) had an initial enzyme activity below $9 \mathrm{U} / \mathrm{ml}$ pRBC. TPMT enzyme activity was measured at 6 different points in time from diagnosis until up to 24 months after the end of maintenance therapy. The TPMT enzyme activity in wild-type individuals increased significantly and reached its highest value at day 106 (median TPMT 14.9 versus $9.5 \mathrm{U} / \mathrm{ml}$ pRBC at diagnosis, $\mathrm{p}=0.001$ ), (Figure 1 ). The four individuals heterozygous for TPMT also showed an increase in TPMT enzyme activity during the first three months (median TPMT 8.3 versus $4.7 \mathrm{U} / \mathrm{ml} \mathrm{pRBC}$ ), although not statistically significant. The TPMT enzyme activity seemed to stabilise during the maintenance treatment (Figure 1). 


\section{In vivo effect of MTX on TPMT and 6-MP metabolites}

Samples were obtained at the time for high-dose MTX infusions from those patients when sufficient blood was available for research purposes. TPMT analysis was prioritised over metabolite measurements when a sufficient amount of blood was not available for both assays. During the time period prior to infusion of high-dose MTX and until 66 hours later, The TPMT levels decreased by 9.2 percent (interquartile range -13 to +0.65 percent, $n=21$, $\mathrm{p}=0.013$ ), from the beginning of MTX infusion through 66 hours post infusion whereas meTIMP did not change and TGN levels decreased 18 percent (-26 to -15 percent, $n=15$, $\mathrm{p}=0.006$ ) (Table 3). The median MTX plasma concentration 23 hours from start of infusion was $84 \mu \mathrm{M}$ (interquartile range $57-102 \mu \mathrm{M}, \mathrm{n}=19$ ).

\section{In vitro effect of MTX on TPMT enzyme activity in MOLT4 cells}

The TPMT enzyme activity in MOLT4 cells showed an initial increase after 24 hours of incubation with $90 \mu \mathrm{M}$ MTX. However, a significant decrease to 26 percent of CV was observed after 48 hours, and the enzyme activity was only 1.8 percent after 72 hours (Figure 3). The CV did not affect TPMT enzyme activity as shown from comparisons with untreated MOLT4 cells in Figure 2.

\section{In vitro effect of MTX on TPMT enzyme activity of the recombinant protein}

The hydrophobic active site of TPMT (Figure 3A) harbours three out of the five tryptophans in the structure of TPMT (Figure 3B). To determine whether MTX is a potential ligand to TPMT, tryptophan fluorescence (with titration of MTX to TPMT) was performed. Figure 4 shows that the binding profile of MTX to TPMT and the $\mathrm{K}_{\mathrm{d}}$ of approximately $24 \mu \mathrm{M}$ could be determined. The remaining enzyme activity of the recombinant wild-type TPMT protein after incubation was 16 percent with $200 \mu \mathrm{M}$ MTX. 


\section{Discussion}

In this study it has been shown that TPMT enzyme activity fluctuated from time of diagnosis throughout the time of treatment. At time of diagnosis, 40 percent of TPMT wild-type ALL patients displayed a deceptively low TPMT enzyme activity compared to genotype (Figure 1). TPMT heterozygous individuals had a TPMT enzyme activity within the range of our reference values (2.5-8.9 U/ml pRBC). In TPMT wild-types, TPMT enzyme activity increased from start of treatment, at least until day 106, when all TPMT wild-type individuals showed a TPMT enzyme activity above $9 \mathrm{U} / \mathrm{ml}$ pRBC. Even though not specifically investigated in our study, the RBCs do not constitute a homogenous group and the RBCs have a life span of 120 days. Lennard et al. (2001) showed that the RBC population at diagnosis was influenced by the disturbed haematopoiesis and the population consisted of an excess of old RBCs [14]. In that study, a density gradient centrifugation of the red blood cells showed that the population corresponding to the older cells displayed a lower TPMT enzyme activity compared to newer cells. In our study, the TPMT enzyme activity increased the first three months, in accordance with the theory that the increase in enzyme activity reflects the recovering haematopoiesis in the patients. However, other drugs could affect TPMT enzyme activity although it is difficult to say what impact these drugs may have on the enzyme activity compared to the RBC age. Also, RBC transfusion may have an impact on the TPMT activity, although Brouwer et al., (2005) showed that this effect was not significant for wild type individuals receiving transfusions [15]. Determining TPMT enzyme activity at diagnosis may lead to a deceptively low TPMT value which could then lead to the risk to initially under-treating the patient, particularly if this result is used to determine the starting dose of 6-MP. Preferably, TPMT genotyping should be performed using techniques that allow for the detection of novel/rare variants, however, most laboratories only genotype for the three most common TPMT sequence variants. Our results 
is in accordance with a recently published paper in a large cohort of ALL patients in UK $[16]$.

\section{In vivo and in vitro effects of MTX on TPMT and 6-MP metabolites}

When measuring TPMT enzyme activity, TGN and meTIMP levels before and after highdose MTX infusions in children already on oral 6-MP treatment, we found a median decrease in TPMT enzyme activity of 9.2 percent 66 hours after start of MTX infusion (Table 3). Despite the decrease in enzyme activity, we did not see any effect on meTIMP levels at the same time point. TGN levels decreased which is a result in accordance with previous studies [17-18]. Zaza et al. (2005) investigated gene expression and TGN levels after high-and low dose MTX infusions in leukemic blasts and showed that patients treated with 6-MP alone achieved higher TGN concentrations than those treated with the combination of 6-MP and MTX. Furthermore, there were distinct sets of upregulated genes in each treatment group [18]. We hypothesise that the interaction between the TPMT protein and MTX is prompt, however, the effect of this inhibition on the metabolism in the context of TGN and meTIMP formation may be a phenomenon seen at a later time point. It could also be that other mechanisms such as those discussed above, will mask the effect of TPMT inhibition on drug metabolism.

A study by de Beaumais et al. (2011), which aimed to examine metabolite levels during treatment, discovered that TGN levels were dependent on TPMT genotype as well as the patient's age, whereas meTIMP was dependent on TPMT and ITPA genotypes [19]. ITPase deficiency has been shown as a risk factor for 6-MP toxicity [2]. 
In this study, the metabolite levels were only measured prior to and after one occasion of MTX infusions. The effect of ITPA genotype on metabolite levels during treatment was a subject that the authors felt went beyond the scope of this article.

To the knowledge of the authors, no study has yet investigated the interaction between 6-MP and MTX by focussing specifically on the influence of MTX on TPMT enzyme activity. The decrease in TPMT enzyme activity was intriguing, and by using recombinant TPMT protein and biophysical characterisation studies of TPMT were carried out when incubated with MTX in vitro. The hypothesis was that MTX was a potent ligand to TPMT due to effects on TPMT enzyme activity after high-dose MTX infusions in children with ALL. The determined crystal structure of the three-dimensional human TPMT [20] showed an active site (Figure 3A) with a large hydrophobic cavity possible of binding purine analogues as well as other hydrophobic compounds. Experiments in our laboratory have shown that, for example, the hydrophobic compound anilino-naphtalene sulfonate (ANS) binds to TPMT with high affinity (data not shown). The protein sequence of TPMT contains five tryptophans, three of them situated in or near the active site (Figure 3B). A method that used fluorescence to study the quenching of tryptophans when adding MTX was used in this study in order to investigate potential binding. The titration of MTX to recombinant TPMT protein (Figure 4) showed binding with an approximate $\mathrm{K}_{\mathrm{d}}$ of $24 \mu \mathrm{M}$. Taking into account that the median plasma concentration of MTX after 23 hours of infusion was $84 \mu \mathrm{M}$, the conclusion that has been drawn is that MTX binds to TPMT at relevant physiological concentrations. A leukemic cell line (MOLT4) was also used and the authors also investigated the effect of $90 \mu \mathrm{M}$ MTX on the TPMT enzyme activity after 24, 48 and 72 hours of incubation. During the first 24 hours of incubation, an increase in TPMT enzyme activity was detected; however, after 48 hours a significant decrease was found in enzyme activity compared to CV (26 percent of CV, $\mathrm{p}<0.001$ ), an inhibition that continued over time; after 72 hours the enzyme activity was almost undetectable. We cannot rule out the 
possibility that the decrease in TPMT activity partly is reflecting an antiproliferative effect of MTX, even though our activity measurements as always done in the same number of cells. It is not clear as to why the enzyme activity increased at the beginning of MTX incubation. A study by Brouwer et al. 2005 [15], showed that TPMT enzyme activity increased in MOLT4 cells after incubation with MTX, however, in their study, cells were simultaneously treated with methionine, thus creating increased amounts of SAM in the cells. As SAM stabilises TPMT it could be that the increase in enzyme activity is due to SAM, not to MTX [21].

\section{Conclusion}

In childhood ALL, the TPMT status should be determined by using TPMT genotyping. Genotyping is preferable as enzyme activity measurement during the first 106 days of treatment will lead to a misclassification. This could potentially lead to initial under-dosing of these individuals. Preferably, the genotyping technique should allow for detection of novel variants. MTX binds to TPMT in vitro and inhibits the enzyme activity both in vitro and in children with ALL after high-dose MTX infusions. Understanding the mechanisms of drug synergism as well as other causes for differences in drug response is important in order to improve treatment and decrease treatment-related toxicity.

\section{Competing Interests}

There are no competing interests to declare.

\section{Acknowledgements}

This study was supported by The Swedish Childhood Cancer Foundation, The Swedish Cancer Society, The Swedish Medical Research Council and The LiU Cancer Network. We 
would like to thank the children and their parents/guardians for their participation in the present study as well as the medical and nursing staff who made this work possible. The skilful technical assistance of Karin Skoglund, Britt Sigfridsson and Monica Häger has also been greatly appreciated. 


\section{References}

1 Schmiegelow K, Forestier E, Hellebostad M, Heyman M, Kristinsson J, Soderhall S, Taskinen M (2010) Long-term results of NOPHO ALL-92 and ALL-2000 studies of childhood acute lymphoblastic leukemia. Leukemia 24 (2): 345-354

2 Stocco G, Cheok MH, Crews KR, Dervieux T, French D, Pei D, Yang W, Cheng C, Pui CH, Relling MV, Evans WE (2009) Genetic polymorphism of inosine triphosphate pyrophosphatase is a determinant of mercaptopurine metabolism and toxicity during treatment for acute lymphoblastic leukemia. Clin Pharmacol Ther 85 (2): 164-172

3 Weinshilboum R, Sladek SL (1980) Mercaptopurine pharmacogenetics: monogenic inheritance of erythrocyte thiopurine methyltransferase activity. Am J Hum Genet 32 (5): 651-662

4 Relling MV, Hancock ML, Rivera GK, Sandlund JT, Ribeiro RC, Krynetski EY, Pui CH, Evans WE (1999) Mercaptopurine therapy intolerance and heterozygosity at the thiopurine S-methyltransferase gene locus. J Natl Cancer Inst 91 (23): 2001-2008

$5 \quad$ Evans WE, Horner M, Chu YQ, Kalwinsky D, Roberts WM (1991) Altered mercaptopurine metabolism, toxic effects, and dosage requirement in a thiopurine methyltransferase-deficient child with acute lymphocytic leukemia. J Pediatr 119 (6): 985-989

6 Finkelstein JD (1990) Methionine metabolism in mammals. J Nutr Biochem 1 (5): 228-237

7 Dervieux T, Brenner TL, Hon YY, Zhou Y, Hancock ML, Sandlund JT, Rivera GK, Ribeiro RC, Boyett JM, Pui CH, Relling MV, Evans WE (2002) De novo purine synthesis inhibition and antileukemic effects of mercaptopurine alone or in combination with methotrexate in vivo. Blood 100 (4): 1240-1247

8 Gregers J, Christensen IJ, Dalhoff K, Lausen B, Schroeder H, Rosthoej S, Carlsen N, Schmiegelow K, Peterson C (2010) The association of reduced folate carrier $80 \mathrm{G}>\mathrm{A}$ polymorphism to outcome in childhood acute lymphoblastic leukemia interacts with chromosome 21 copy number. Blood 115 (23): 4671-4677

9 Lindqvist M, Haglund S, Almer S, Peterson C, Taipalensu J, Hertervig E, Lyrenas E, Söderkvist P (2004) Identification of two novel sequence variants affecting thiopurine methyltransferase enzyme activity. Pharmacogenetics 14 (4): 261-265

10 Hindorf U, Appell ML (2012) Genotyping should be considered the primary choice for pre-treatment evaluation of thiopurine methyltransferase function. $\mathrm{J}$ Crohns Colitis 6 (6): 655-659

11 Pettersson B, Almer S, Albertioni F, Söderhall S, Peterson C (2002) Differences between children and adults in thiopurine methyltransferase activity and metabolite formation during thiopurine therapy: Possible role of concomitant methotrexate. Ther Drug Monit 24 (3): 351-358

12 Appell ML, Wennerstrand P, Peterson C, Hertervig E, Martensson LG (2010) Characterization of a novel sequence variant, TPMT*28, in the human thiopurine methyltransferase gene. Pharmacogenet Genomics 20 (11): 700-707 
13 Krynetski EY, Krynetskaia NF, Yanishevski Y, Evans WE (1995) Methylation of mercaptopurine, thioguanine, and their nucleotide metabolites by heterologously expressed human thiopurine S- methyltransferase. Mol Pharmacol 47 (6): 1141-1147

14 Lennard L, Chew TS, Lilleyman JS (2001) Human thiopurine methyltransferase activity varies with red blood cell age. Br J Clin Pharmacol 52 (5): 539-546

15 Brouwer C, De Abreu RA, Keizer-Garritsen JJ, Lambooy LH, Ament K, ter Riet PG, van Wering ER, Trijbels FJ, Veerman AJ, Hoogerbrugge PM, Bokkerink JP (2005) Thiopurine methyltransferase in acute lymphoblastic leukaemia: biochemical and molecular biological aspects. Eur J Cancer 41 (4): 613-623

16 Lennard L, Cartwright CS, Wade R, Richards SM, Vora A (2012) Thiopurine methyltransferase genotype-phenotype discordance, and thiopurine active metabolite formation, in childhood acute lymphoblastic leukaemia. Br J Clin Pharmacol doi 101111/bcp12066

17 Dervieux T, Hancock ML, Pui CH, Rivera GK, Sandlund JT, Ribeiro RC, Boyett J, Evans WE, Relling MV (2003) Antagonism by methotrexate on mercaptopurine disposition in lymphoblasts during up-front treatment of acute lymphoblastic leukemia. Clin Pharmacol Ther 73 (6): 506-516

18 Zaza G, Cheok M, Yang W, Panetta JC, Pui CH, Relling MV, Evans WE (2005) Gene expression and thioguanine nucleotide disposition in acute lymphoblastic leukemia after in vivo mercaptopurine treatment. Blood 106 (5): 1778-1785

19 Adam de Beaumais T, Fakhoury M, Medard Y, Azougagh S, Zhang D, Yakouben K, Jacqz-Aigrain E (2011) Determinants of mercaptopurine toxicity in paediatric acute lymphoblastic leukemia maintenance therapy. Br J Clin Pharmacol 71 (4): 575-584

20 Wu H, Horton JR, Battaile K, Allali-Hassani A, Martin F, Zeng H, Loppnau P, Vedadi M, Bochkarev A, Plotnikov AN, Cheng X (2007) Structural basis of allele variation of human thiopurine-S-methyltransferase. Proteins 67 (1): 198208

21 Milek M, Karas Kuzelicki N, Smid A, Mlinaric-Rascan I (2009) Sadenosylmethionine regulates thiopurine methyltransferase activity and decreases 6-mercaptopurine cytotoxicity in MOLT lymphoblasts. Biochem Pharmacol 77 (12): 1845-1853 
FIGURE LEGENDS

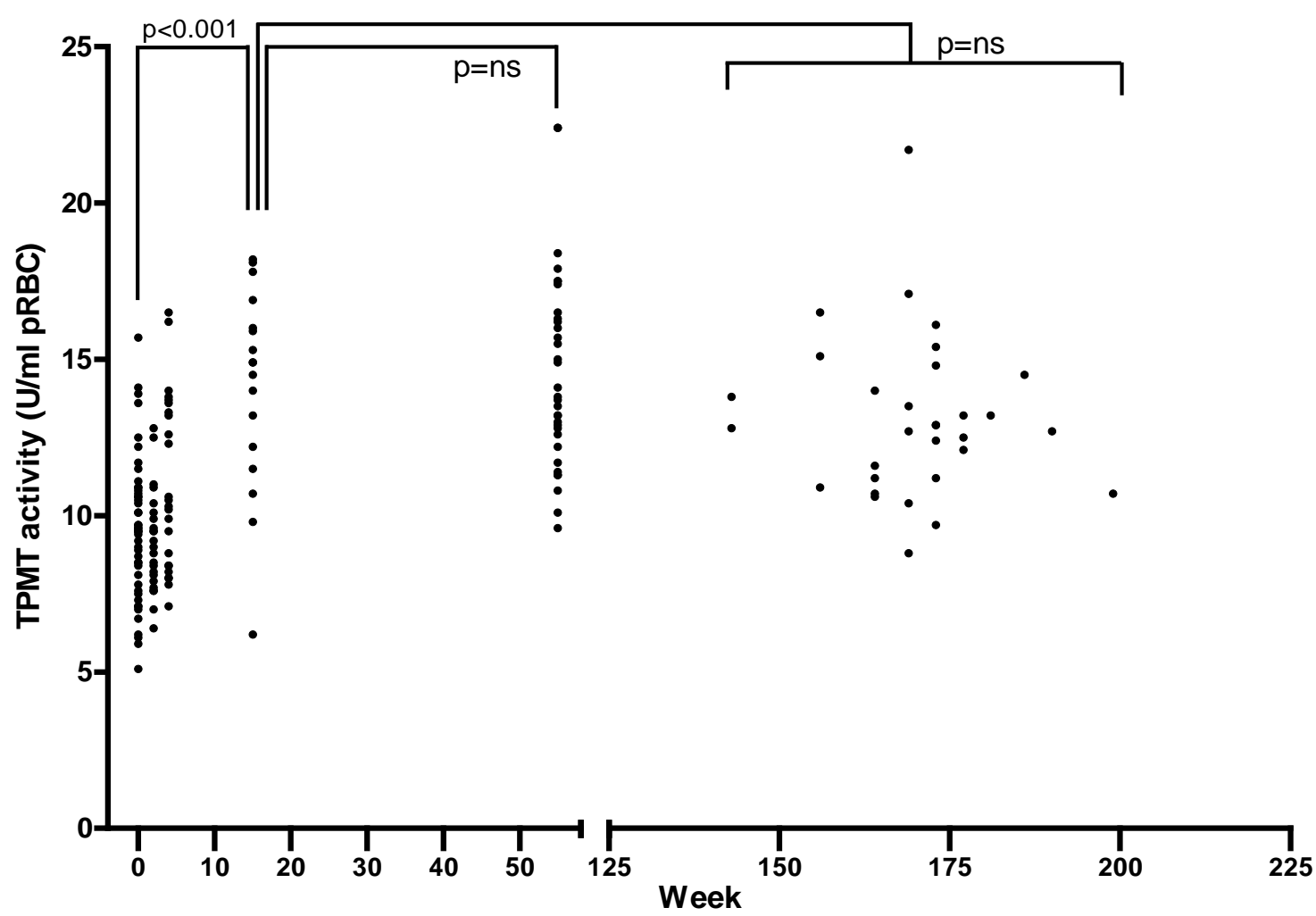

Figure 1. TPMT activity in 47 TPMT wild-type children with ALL from diagnosis until up to 2 years after cessation of maintenance therapy. Patients were sampled at 5 occasions during treatment protocol, and one time from 3 months up to 24 months after cessation of therapy. ns= non-significant differences between time points. TPMT activity increased the first 18 weeks of treatment. 


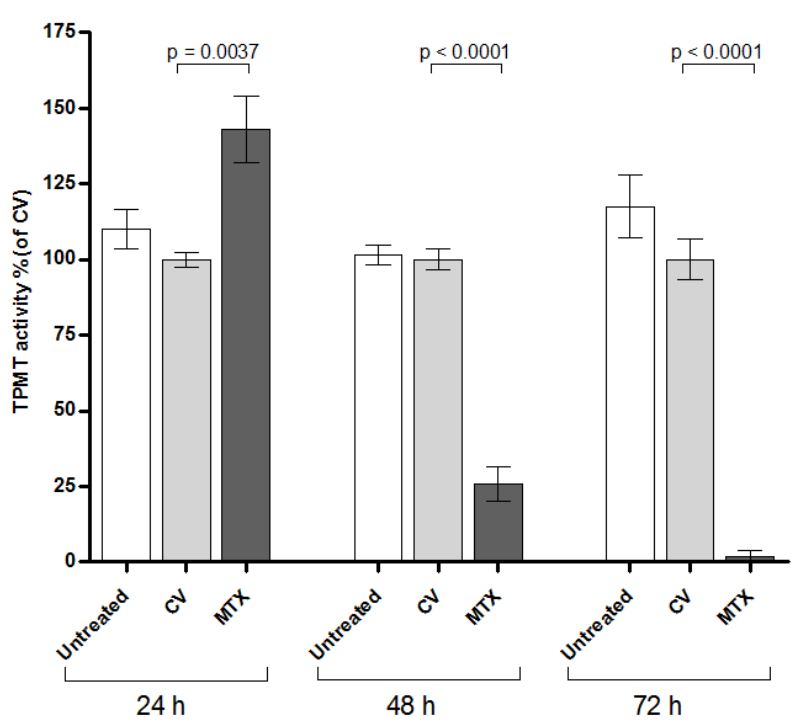

Figure 2. TPMT activity in MOLT4 cells after 24, 48 and $72 \mathrm{~h}$ of incubation with methotrexate (MTX, final concentration $90 \mu \mathrm{M}$ ). Results are shown as mean percentage of respective control vehicle $(\mathrm{CV}) \pm \mathrm{SEM}(\mathrm{N}=6)$. The TPMT activity in untreated cells compared to cells treated with CV is also shown. TPMT activity was increased the first $24 \mathrm{~h}$ of incubation. At $48 \mathrm{~h}$, the TPMT activity was only $26 \%$ of CV treated cells, and the activity was only $1.8 \%$ after $72 \mathrm{~h}$. 
A

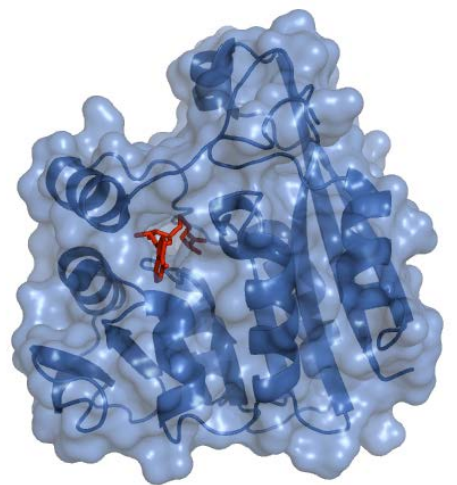

B

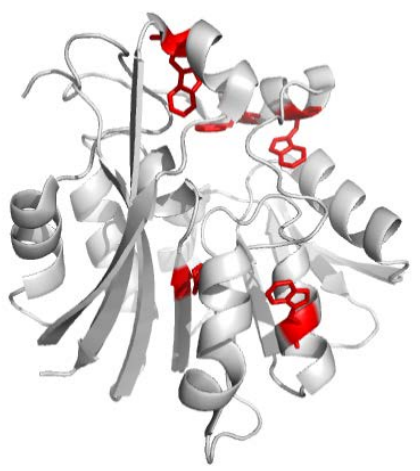

Figure 3. A) Three-dimensional structure of human TPMT illustrating the active site with the co product S-adenosyl L- homocysteine (PDB code 2BZG) in red. B) Three-dimensional structure of human TPMT illustrating tryptophan positions (red), (PDB code 2BZG) 


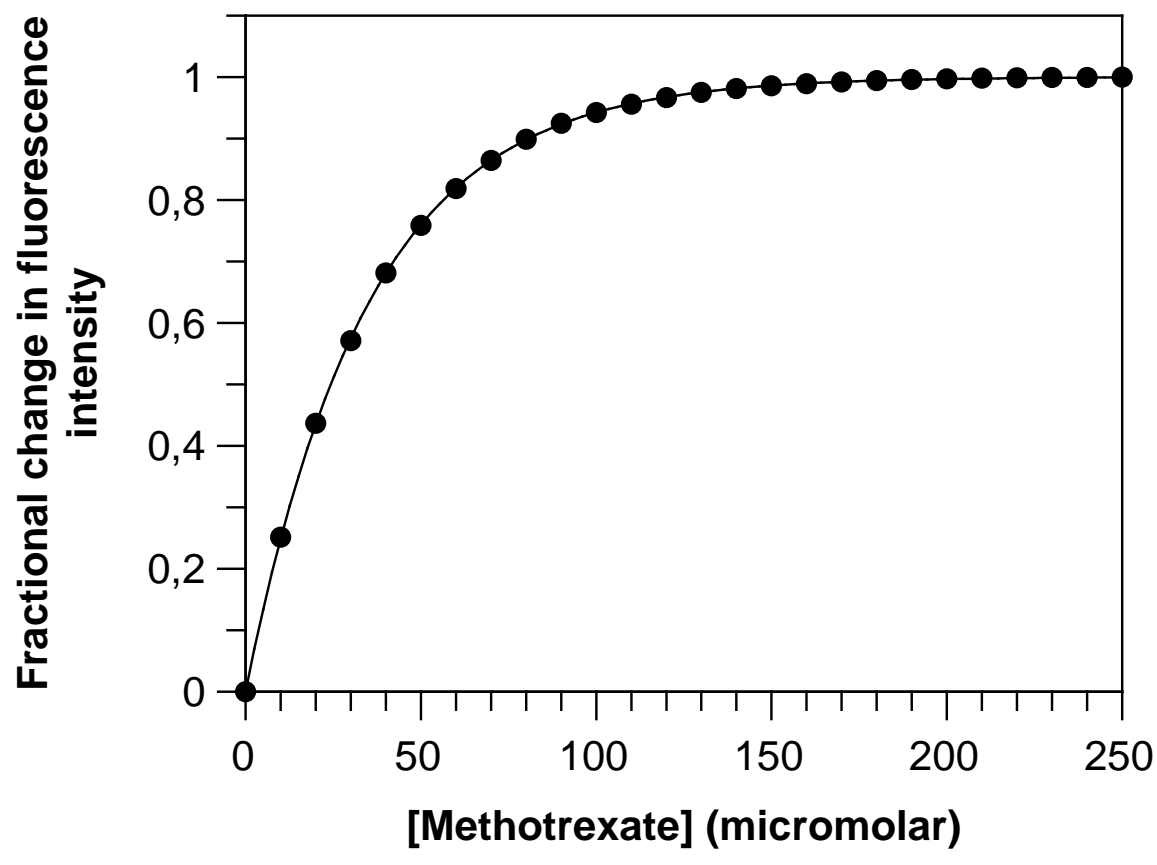

Figure 4. Titration of 0 to $250 \mu \mathrm{M}$ methotrexate to human recombinant TPMT as monitored by tryptophan fluorescence intensity at $340 \mathrm{~nm}$. 
Table 1. Patient Characteristics

\begin{tabular}{lll}
\hline Diagnosis & Pre-B-ALL & $49(92.5 \%)$ \\
& T-ALL & $4(7.5 \%)$
\end{tabular}

\begin{tabular}{|c|c|c|}
\hline ALL-2000 protocol & Extra Intensive (EI) & $2(3.8 \%)$ \\
\hline & Very intensive (VI) & $2(3.8 \%)$ \\
\hline & Intensive (I) & $6(11.3 \%)$ \\
\hline & Intermediate Intensive (II) & $23(43.4 \%)$ \\
\hline & Standard Intensive (SI) & 20 (37.7\%) \\
\hline Gender & Male & $24(45.3 \%)$ \\
\hline & Female & $29(54.7 \%)$ \\
\hline Age & Median year (Range) & $7.5(1-17)$ \\
\hline TPMT genotype & TPMT*1/*1 & 49 (92.5\%) \\
\hline & $T P M T * 1 / * 3 A$ & $3(5.7 \%)$ \\
\hline & $T P M T * 1 / * 3 C$ & $1(1.9 \%)$ \\
\hline
\end{tabular}

Factors stratifying patients to the respective therapy group:

EI; WBC $>200.1 \times 10^{9} /$ l, very slow response (Day 29: M3)

VI; Age $>5$ years, WBC $100.1-200 \times 10^{9} / \mathrm{l},>5$ years, CNS-ALL, $>5$ years, T-cell ALL with mediastinal mass.

I; WBC $\leq 100 \times 10^{9} /$ l, rest of the patients according to high risk criteria.

II; Age 1 to $<10$ years and WBC $10.1-\leq 50.0 \times 10^{9} / 1$ or Age $\geq 10$ years and $\mathrm{WBC} \leq 50.0 \mathrm{x}$ $10^{9} /$. No high risk criteria. 
HR-criteria; WBC, 11q23/MLL- rearrangements, t(9;22)(q34;q11)/BCR-ABL, t(1;19)(q23;p13)/E2A-PBX1, Hypodiploidy (<45 chromosomes), T-cell ALL, CNS-ALL, Testis ALL, Poor response (BM Day 15: M3 and/or BM Day 29: M2 or M3).

SI; Age, 1 to $<10$ years and $\mathrm{WBC} \leq 10.0 \times 10^{9} /$, No high risk criteria 
Table 2. Flowchart of available blood samples during study

\begin{tabular}{|l|l|l|l|l|l|l|}
\hline $\begin{array}{l}\text { TPMT } \\
\text { genotype }\end{array}$ & At diagnosis & Day 15 & Day 29 & Day 106 & $\begin{array}{l}\text { Day 400 } \\
\text { (during the } \\
\text { maintenance } \\
\text { treatment) }\end{array}$ & $\begin{array}{l}\text { Follow up } \\
\text { (>3 months } \\
\text { after end of } \\
\text { treatment) }\end{array}$ \\
\hline All patients & $51\left(53^{\beta}\right)$ & 27 & 27 & 20 & 36 & 35 \\
\hline $\begin{array}{l}\text { TPMT wild } \\
\text { type }\end{array}$ & $47\left(49^{\beta}\right)$ & 23 & 24 & 17 & 33 & 33 \\
\hline $\begin{array}{l}\text { TPMT } \\
\text { heterozygous }\end{array}$ & 4 & 4 & 3 & 3 & 3 & 2 \\
\hline
\end{tabular}

${ }^{\beta}$ Two TPMT wild type individuals were not available for follow up samples. 


\section{Table 3}

Median (interquartile range) pre-HDMTX infusion TPMT (U/ml pRBC), RBC TGN and meTIMP levels (pmol/8x10 $\mathrm{RBC}$ ) with percentage change around 66 hours after initiation of HD-MTX.

\begin{tabular}{|c|c|c|c|}
\hline & $\begin{array}{l}0 \text { hours } \\
\text { (pre- } \\
\text { infusion) }\end{array}$ & $\begin{array}{l}\sim 66 \text { hours } \\
\text { \% change }\end{array}$ & $\begin{array}{l}\text { Change versus } \\
\text { pre-infusion } \\
\text { values }\end{array}$ \\
\hline TPMT (U/ml pRBC) & $\begin{array}{c}13.4 \\
(11.4-16.2)\end{array}$ & $\begin{array}{c}-9.2 \\
(-13.0 \text { to }+0.65)\end{array}$ & $\mathrm{P}=0.013 \mathrm{~N}=21$ \\
\hline TGN (pmol/8x10 RBC) & $\begin{array}{c}111.5^{\beta} \\
(79-271)\end{array}$ & $\begin{array}{c}-18.1 \% \\
(-26 \text { to }-14.6)\end{array}$ & $\mathrm{P}=0.006 \mathrm{~N}=15$ \\
\hline $\operatorname{meTIMP}\left(\mathrm{pmol} / 8 \times 10^{8} \mathrm{RBC}\right)$ & $\begin{array}{c}1609^{\beta} \\
(427-3900)\end{array}$ & $\begin{array}{c}0 \% \\
(-20.5 \text { to }+36)\end{array}$ & $\mathrm{P}=0.917 \mathrm{~N}=15$ \\
\hline
\end{tabular}

${ }^{\beta}$ Normalized metabolite levels were calculated by dividing the metabolite levels with daily 6-MP dose. TPMT: Thiopurine methyltransferase; TGN: Thioguanine nucleotides; meTIMP: methylthioinosine monophosphate. 